\title{
Tariff Setting as Investment Guarantee on Public to Private Cooperation in Infrastructure Development
}

\author{
Yosua Lusopatia Tobing ${ }^{1}$, Evita Isretno Israhadi ${ }^{2}$ \\ Borobudur University, Jl. Kalimalang No. 1, Jakarta ${ }^{1,2}$ \\ \{Josh.tobing@gmailcom¹, Evita_isretno@borobudur.ac.id $\left.{ }^{2}\right\}$
}

\begin{abstract}
The construction of infrastructure facilities has traditionally been the government's obligation as the administrator of the state. However, the government may have a limited budget and resources to perform such duties. The government then involves private sectors in building, financing, and managing infrastructure development needs to do. Investors will get a return on their investment through tariffs on the use of such infrastructure facilities. This paper discusses the importance of certainty to the contractual tariff increase for investors while on the other hand, the government needs to consider the public's affordability at the new tariff. The research uses the Indonesian infrastructure project, specifically toll road concession, as a case study.
\end{abstract}

Keywords: Tariff Setting; Investment Guarantee; Public to Private Cooperation; Infrastructure Development

\section{Introduction}

For developing countries such as Indonesia, infrastructure development is an important project as the foundation for other development projects and the lives of the community in general. Physical infrastructure includes highways (including toll roads), railways, seaports, airports, transportation equipment, telecommunications, electricity, gas installations, clean water distribution, etc. Physical infrastructure can be a complex blessing in both topologies and tingling with social systems (Guidotti et al., 2019). The general characteristics of infrastructure are concerning the lives of many people, and its construction costs are enormous. That is why infrastructure development in developing countries is often an issue due to financial matters (Man et al., 2015). Given the enormous costs required to carry out these projects, the government involves the private sector as investors and operators who are professionals of the infrastructure facilities. Government and private cooperation are often referred to as public to private participation (PPP) (Fang et al., 2019).

The investor expects a return on his investment with the desired level of return (IRR parameter). The investor will receive income through infrastructure facilities users who will pay the tariffs which the government has set, such as toll road tariffs (Panou, 2020). The government shall set up the initial tariff and adjust it regularly as stipulated in concession agreements, at least to cover the inflation. However, the government has other considerations in setting the tariffs, including socio-political conditions. For instance, in the occurrence of Covid-19 pandemic, the government tends to delay the increase in toll road tariffs, which 
already due contractually, not to provide more burden to the community. So, what about the level of return on investment that investors expect? Isn't the tariff-setting mechanism promised in the concession contractual and binding?

The identified problem is how the legal certainty of private investment return in PPP project through tariffs imposed by the government. Can the determination of tariffs be tied up in a government-private cooperation contract to ensure the certainty of return on investment and profit? How strong is the provision of tariffs' determination can be promised and binding between the government and concession holders (investors)?

\section{Methodology}

The research method used is literature research method that is Normative Juridical or Normative Research. The library materials used are legislation on The Determination of Tariffs for the use of infrastructure facilities especially in toll roads, and concession agreements (as an example), supported by scientific papers published in official journals. Thus, the type of research carried out is indirect research with data collection tools in the form of document studies. The research type is problem-solving.

\section{Result and Discussion}

In Indonesia, cooperation between government and business entities is regulated in Presidential Regulation No. 38 of 2015 concerning Government Cooperation with Business Entities in Infrastructure Provision ("Presidential Regulation 38"). The return on investment of implementing business entities from the provision of infrastructure derived from a) tariffs paid by users of infrastructure facilities; b) Availability Payment; and/or c) other forms to the extent they do not conflict with prevailing laws and regulations. Considering PPP's objectives to reduce government spending on physical infrastructure funding, the preferable source will be from the tariffs paid by infrastructure facilities.

In adjusting tariffs, the government only needs to comply with the laws and regulations on tariffs and the concession agreements that bind them to investors. In the reality, the government is a political institution with the main task of its people's welfare. How to bridge this gap? The government's position as a party to concession agreements and the government's role as an authority to prosper its people. The government intervention in the tariff setting should ensure both the concession owners' interest and the users' interest (Matanovac Vučković, 2016).

The investors already bear business risks, especially sales risks or traffic levels for transportation infrastructure, in addition to the risks of construction, operational, and maintenance costs of infrastructure facilities. Initial traffic forecasts are often lower than they are (Wibowo et al., 2012). Investors naturally bear the risk of this business because it is, to a certain extent, within the control of the operator's investors. If investors want a larger sales volume, investors must serve their customers in better ways. To attract more vehicles to use the toll road, its facilities must be better than public roads. To generate more profit, the operational and maintenance costs must be spent as efficiently as possible, and so on and so forth.

Should the government want to attract more investors to participate in infrastructure development, the risks of failure or delay in adjusting the promised tariffs should not be 
addressed to investors. Physical infrastructure investment is critical and directly impacts a country's welfare as measured by GDP (Javid, 2019).

Generally, concession agreements between governments and investors or infrastructure operators require specific criteria as a prerequisite for regular fare increases. In toll road concession, minimum service standards must be met by the operator at the time of applying for a regular tariff increase. Contractually, if the condition is met, the government shall provide the tariff adjustment as the operator's contractual right, periodically at a particular time. As an example, Mojokerto-Jombang Toll Road Concession Agreement, deed of Notary Rina Autami Djauhari number 21 dated June 28, 2011, article 11.4.1 stipulates that the toll road operator entitled for a tariff adjustment every 2 years based on inflation as referred to Central Statistical Bureau (BPI) applicable data for the area.

Absence or delay in adjusting tariffs that are not due to the operator's negligence to meet his contractual obligations needs to be avoided (Wibowo, 2004). Results to fare delays:

a. Investor' financial capabilities are declining, which could affect his ability to perform operations and maintenance (O\&M) of infrastructure facilities. The cost of operating and maintaining infrastructure facilities is not small, besides the operator must pay its debt to the creditors every month. If investors' income is not sufficient to bear these burdens, consequently, the community's services will be disrupted. For example, in toll road infrastructure, when toll road re-paving or repair of lighting and road signs are not carried out routinely, the comfort and safety of toll road users become disturbed. If the investors fail to pay the debt, the bank can take over the toll road operation, and the transition may also reduce the comfort of toll road users. Eventually, this condition will burden the community users of infrastructure facilities themselves.

b. Legal certainty over investment becomes neglected. This will reduce the government's credibility in the eyes of investors (local and foreign) and directly reduce investors' interest in investing in infrastructure in Indonesia. If this happens, then the government's ability to build infrastructure becomes disrupted because it has to finance the infrastructure development (all over the country) on its own. Finally, economic growth will not happen as expected, the welfare of the community did not materialize.

Delays in increasing infrastructure usage rates in the short term may please customers/users of facilities, but for the long term none of the above consequences benefit both the government and the public, including customers, especially for investors who have suffered first.

Wherever possible, the government should consistently carry out its obligations under the concession agreement. Partiality to the people can be considered but this is not the case if the government only wants to be populist to maintain his political power (e.g., in the context of elections or elections). It is not right to retain political power by sacrificing its counterpart in the concession agreement. Ultimately this burden must be borne by the community as well if investors' financial capabilities are reduced, and the maintenance and operational activities of infrastructure facilities are disrupted.

If the community's condition has not been possible to bear higher rates, the tariff adjustment may temporarily be withheld, but it must be sought so that the delay is not too long. The government must compensate investor losses due to delays in tariff increases that are not due to its negligence in concession agreements. The government should respect the concession agreement because the government's position in the agreement is equal with the investors (a subject of private law). Forms of compensation can be made, among others, by compensating the losses on subsequent tariff increases or extending the concession period. 
This compensation mechanism should be regulated in concession agreements to provide comfort for investors.

Compensation mechanisms may not adequate to overcome operators' inability to perform operations and maintenance when the fare increase has not occurred. The compensation is not always applicable, and operators do not always receive the compensation immediately although the mechanisms are stipulated in the concession contract (Panou, 2020). It could be that the operator is not strong enough to bear the financial burden that occurs during the delay of the tariff adjustment period if the delay occurs too long.

\section{Conclusion}

The primary source of income for infrastructure operator investors is from the tariffs that customers pay. In the concession agreement, the government promises to regularly increase the tariff based on the inflation if the operator meets minimum service requirements, which has become the basis for investors' calculations to enter the infrastructure business. The government shall respect its contractual obligation to adjust the tariff under the concession agreements and shall provide reasonable compensation for the delay. The compensation mechanism must be stipulated clearly in the concession agreement, in Indonesian toll road concession practice it can be compensated in the subsequent tariff adjustment or extension to the concession period. With proper drafting arrangements on the concession agreements and consistent implementation by the government, the tariffs-setting can be used as an investment guarantee to the investors to invest in infrastructure development thus attract more investors in the physical infrastructure business.

\section{References}

[1] Fang, Y., Wei, W., Liu, F., Mei, S., Chen, L., \& Li, J. (2019). Improving Solar Power Usage with Electric Vehicles: Analyzing a Public-private Partnership Cooperation Scheme Based on Evolutionary Game Theory. Journal of Cleaner Production, 233, 1284-1297. https://doi.org/10.1016/j.jclepro.2019.06.001

[2] Guidotti, R., Gardoni, P., \& Rosenheim, N. (2019). Integration of physical infrastructure and social systems in communities' reliability and resilience analysis. Reliability Engineering and System Safety, 185(January), 476-492. https://doi.org/10.1016/j.ress.2019.01.008

[3] Javid, M. (2019). Public and private infrastructure investment and economic growth in Pakistan: An aggregate and disaggregate analysis. Sustainability (Switzerland), 11(12). https://doi.org/10.3390/SU11123359

[4] Man, Q., Sun, C., Fei, Y., Skitmore, M., Bai, Y., \& Lu, W. (2015). Government motivation-embedded return guarantee for urban infrastructure projects based on real options. Journal of Civil Engineering and Management, 22(7), 954-966. https://doi.org/10.3846/13923730.2016.1204362

[5] Matanovac Vučković, R. (2016). Implementation of Directive 2014/26/EU on Collective Management and Multi-Territorial Licensing of Musical Rights in Regulating the Tariff-Setting Systems in Central and Eastern Europe. IIC International Review of Intellectual Property and Competition Law, 47(1), 28-59. https://doi.org/10.1007/s40319-015-0438-5 
[6] Panou, K. (2020). An empirical model for setting and adjusting road-toll rates based on optimized equity and affordability strategies. Case Studies on Transport Policy, August, 0-1. https://doi.org/10.1016/j.cstp.2020.08.006

[7] Wibowo, A. (2004). Valuing guarantees in a BOT infrastructure project. Engineering, Construction and Architectural Management, 11(6), 395-403. https://doi.org/10.1108/09699980410571543

[8] Wibowo, A., Permana, A., Kochendörfer, B., Kiong, R. T. L., Jacob, D., \& Neunzehn, D. (2012). Modeling Contingent Liabilities Arising from Government Guarantees in Indonesian BOT/PPP Toll Roads. Journal of Construction Engineering and Management, 138(12), 1403-1410. https://doi.org/10.1061/(asce)co.19437862.0000555 